pointed to American religiosity as a factor generally overlooked by intellectuals seeking to explain the workings of American society. Lipset suggested that the high levels of belief in God and in church going reinforces messianism and affects foreign policy. He pointed to the connection between the Protestant tradition of following one's conscience and a uniquely American phenomenon-the presence of a strong anti-war movement during every war except World War II. Americans may be patriotic, but that patriotism has not necessarily meant "our country right or wrong." This moralistic element also has contributed to the tendency to see our enemies as satan, as an evil empire.

With respect to the underclass, Lipset observed that King's comments parallel statements made about the Irisn in the 1850s. He argued that the underclass stems from an open immigrant society and has repeatedly been a source of violence.

Lipset also took issue with King's views on the American economy. He contended that the economy is more open now than in the past, and he counts on a large and continuing influx of immigrants to "refurbish" the United States and keep us from getting soft.

On the question of state power, Lipset discounted Toinet's stress on the longterm existence of a strong, centralized state by citing the recurrent threats to secede before the Civil War and the tendency for members of Congress, during the first 75 years of American history, to leave office, not because they were defeated, but because they preferred serving in state legislatures than in Washington, DC.

\section{Mansbridge Receives Second APSA Award for Why We Lost the ERA}

Jane Mansbridge of Northwestern University shared the Victoria Schuck award for the best book published in 1986 or
1987 on women and politics with Rebecca E. Klatch of the University of California, Santa Cruz. Klatch was recognized for her book. Women of the New Right. Mansbridge's Why We Lost the ERA had previously shared the 1987 Gladys M. Kammerer Award for the best political science publication in the field of U.S. national policy.

Ambassador jeane J. Kirkpatrick, and Jeffrey $H$. Birnbaum and Allan S. Murray of the Wall Street journal were also among those honored at the APSA's 84th annual meeting. John W. Ryan of Indiana University presented Kirkpatrick, former U.S. Ambassador to the United Nations, with the Hubert $\mathrm{H}$. Humphrey Award for notable public service by a political scientist. Birnbaum and Murray were presented with the Carey McWilliams Award by Nelson Polsby of the University of California, Berkeley. Birnbaum and Murray's book, Showdown at Gucci Gulch: Lawmakers, Lobbyists and the Unlikely Triumph of Tox Reform, represented a major journalistic contribution to the understanding of politics.

Kenneth Shepsle of Harvard University and Barry Weingast of the Hoover Institution shared the first Heinz Eulau Award for the best article published in The American Political Science Review in the previous year. Shepsle and Weingast were recognized for their article, "The Institutional Foundations of Committee Power."

The Woodrow Wilson Foundation Award for the best book published in the United States during 1987 on government, politics, or international affairs was awarded to Robert Gilpin of Princeton University for his book. The Political Economy of International Relations.

David Baldwin of Columbia University presented the Gladys $M$. Kammerer Award for the best publication in 1987 on U.S. national policy to Dennis F. Thompson of Harvard University for his book, Political Ethics and Public Office.

The Ralph I. Bunche award for a scholarly work exploring the phenomenon of ethnic and cultural pluralism was received by Earl Black of the University of South Carolina and Merle Black of the University of North Carolina for their book, Politics and Society in the South. 


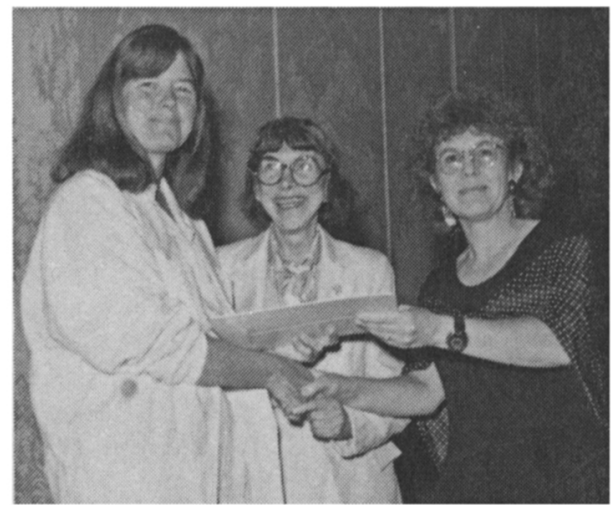

Jane Mansbridge receives the Schuck Award from Victoria Schuck and Jean Bethke Elshtain.

The Franklin L. Burdette Pi Sigma Alpha Award for the best paper presented at the 1987 annual meeting was presented to Ronald Rogowski of the University of California, Los Angeles, for "Changing Exposure to Trade and the Development of Political Cleavages."

James W. Fesler, Yale University Emeritus, was honored at the Third John Gaus Lecture. Professor Fesler delivered the Gaus Lecture, "The State and Its Study: The Whole and the Parts," at the annual meeting. The lecture is presented in this issue of $P S$.

The Association also awarded six dissertation awards:

David Friedman, Los Angeles, California, the Gabriel A. Almond Award, for the best doctoral dissertation completed during 1986 or 1987 in the field of comparative politics, for The Misunderstood Miracle: Politics and the Development of a Hybrid Economy in Japan, submitted by the Massachusetts Institute of Technology; dissertation chair, Richard J. Samuels.

Graham Walker, University of Pennsylvania, the Edward S. Corwin Award for the best doctoral dissertation completed and accepted during 1986 or 1987 in the field of public law, for The Deep Structure of Contemporary Constitutional Controversy: Morality, Skepticism and Augustine, submitted by the University of Notre Dame; dissertation chair, Sotorius Barber.

Aaron L. Friedberg, Princeton University, the Helen Dwight Reid Award, for

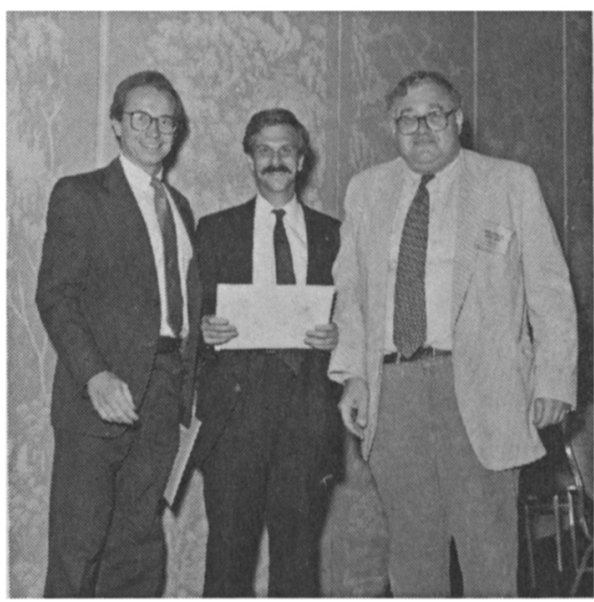

R. to I., Nelson Polsby presents Carey McWilliams Award to Jeffrey $H$. Birnbaum and Alan S. Murray.

the best doctoral dissertation completed during 1986 or 1987 in the field of international relations, law, and politics, for Change, Assessment and Adaptation: Britain and the Experience of Relative Decline, 1895-1905, submitted by Harvard University; dissertation chairs, Stanley Hoffmann and Samuel $P$. Huntington.

Mark C. Westlye, University of California, Berkeley, the E. E. Schattschneider Award for the best doctoral dissertation completed and accepted during 1986 or

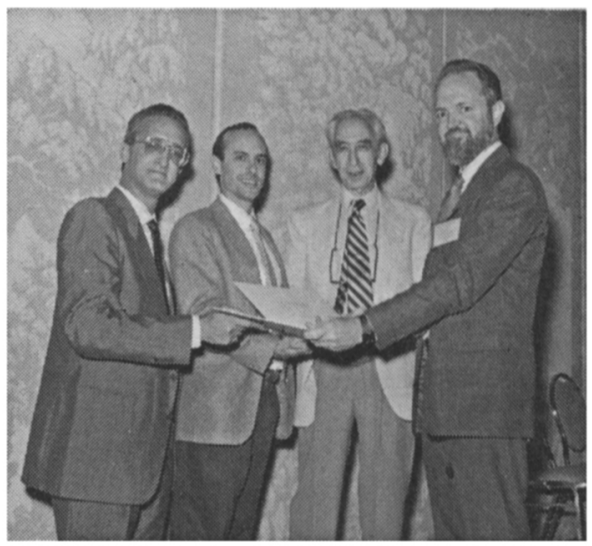

$L$. to $r$., Kenneth Shepsle and Barry Weingast receive Eulau Award from Heinz Eulau and Russell Hardin. 


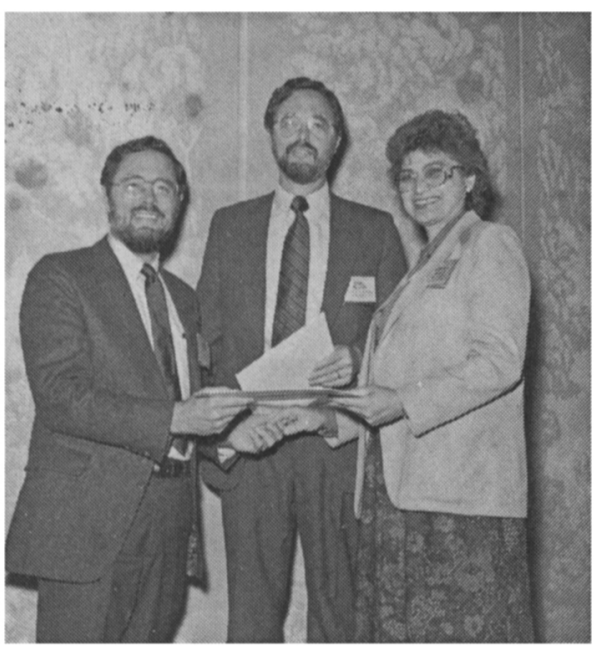

Merle and Earl Black receive the Ralph ). Bunche Award from Rita Mae Kelly.

1987 in the field of American government, for Dynamics of U.S. Senate Elections, submitted by the University of California, Berkeley; dissertation chair, Raymond $E$. Wolfinger.

Peter Berkowitz, Deerfield, llinois, the Leo Strauss Award, for the best doctoral dissertation in the field of political philosophy, for The Foundations of Nietzsche's Political Philosophy, submitted by Yale University; dissertation chair, Joseph Hamburger.

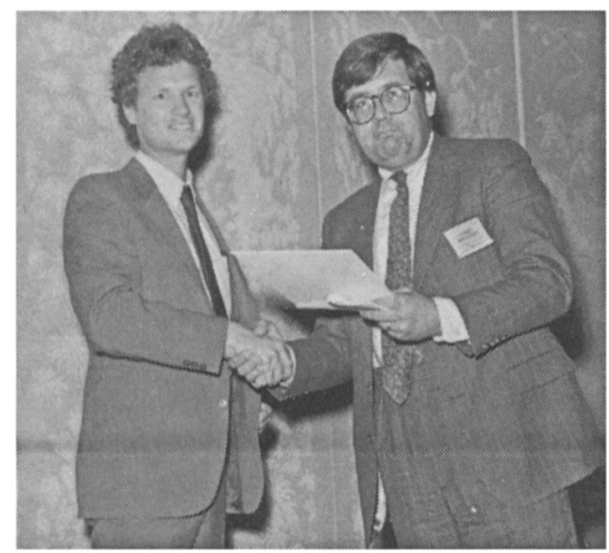

David Magleby presents the E. E. Schattschneider Dissertation Award to Mark Westlye.

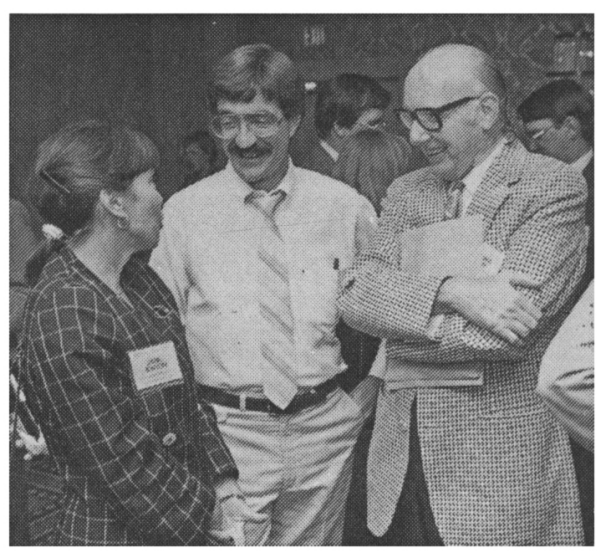

Jane Jenson, Morris Fiorina and William Riker help celebrate the 25th anniversary of the University of Rochester's Ph.D. program.

Chris C. Demchak, U.S. Military Academy, West Point, the Leonard D. White Award, for the best doctoral dissertation in the field of public administration, including broadly related problems of policy formation, for War, Technological Complexity, and the U.S. Army, submitted by the University of California, Berkeley; dissertation chair, Todd R. LaPorte.

Neither the William Anderson Award for the best doctoral dissertation in the field of intergovernmental relations, nor the Harold D. Lasswell Award for the best doctoral dissertation in the field of policy studies were awarded in 1988.

Editor's Note: For the full text of citations, see the Gazette in this issue of PS.

\section{Nelson and Peltason Are Honored at Washington Annual Meeting}

William E. Nelson of Ohio State University and Jack W. Peltason, Chancellor of the University of California-Irvine, were honored by the APSA Committee on the Status of Blacks in the Profession at the annual meeting. Plaques were presented 